This is a self-archived version of an original article. This version may differ from the original in pagination and typographic details.

Author(s): Uusitalo, Outi; Takala, Tuomo

Title: From Scarcity to Abundance : Food Waste Themes and Virtues in Agrarian and Mature Consumer Society

Year: 2020

Version: Accepted version (Final draft)

Copyright: (c) The Authors, 2020

Rights: In Copyright

Rights url: http://rightsstatements.org/page/InC/1.0/?language=en

Please cite the original version:

Uusitalo, O., \& Takala, T. (2020). From Scarcity to Abundance : Food Waste Themes and Virtues in Agrarian and Mature Consumer Society. In E. Närvänen, N. Mesiranta, M. Mattila, \& A. Heikkinen (Eds.), Food Waste Management : Solving the Wicked Problem (pp. 257-288). Palgrave Macmillan. https://doi.org/10.1007/978-3-030-20561-4_10 
From scarcity to abundance: food waste themes and virtues in agrarian and mature consumer society

Outi Uusitalo

Tuomo Takala

Jyväskylä University School of Business and Economics 


\begin{abstract}
Uusitalo and Takala address food waste problem as a societal phenomenon and examine ethical virtues, values linked to them, and food practices in two different time periods, agrarian society (1885-1917) and mature consumer society (2008-2017), in Finland. Their study uses data from newspapers to uncover how ethical principles can underpin understanding of food waste phenomenon. The study shows how the virtues adopted by food chain actors guide their practices towards sustainable ways of handling excess food. While societal themes of food waste are changing, virtues and food practices are changing as well, but some deep-rooted societal virtues and values persist. The chapter concludes with recommendations of how to act out virtues in everyday food practices to control and reduce food waste.
\end{abstract}

Keywords: food waste, virtue ethics, sustainable, consumption, food chain 


\section{From scarcity to abundance: food waste themes and virtues in agrarian and mature consumer society}

\section{Introduction}

Food waste is a severe problem with economic, ecological, social and ethical consequences. Excess food and leftovers arise in the food chain unavoidably, but wasted food has become a critical issue and a recognised problem in recent decades. Numerous international initiatives to address this problem have been launched (Abdelradi, 2018), indicating that avoidance of food waste can be achieved with successful and urgent intervention and solutions from those in power (Filimonau \& Gherbin, 2017). The food waste problem often is attributed mainly to consumers' purchasing habits and consumption patterns (Van Doorn, 2016), sociodemographic factors, situational factors (poor skills, lack of planning, etc.), retail and marketing stimuli, behavioural and cultural factors, and food industry procedures (Porpino, 2016). While these reasons are obvious in explaining consumers' everyday food behaviours and food chain actors' practices, little attention has been paid to the socio-philosophical and ethical issues that may underlie consumers, retailers and food industry actors' food waste behaviours. Food waste, as a societal phenomenon, refers to the economic, social and environmental consequences of food produced, but not consumed. It is a sustainability issue, because the wasted food affects local, global and future stakeholders' well-being (Becker, 2017). This chapter's objective is to broaden the understanding of food waste and its relationship to societal themes, with a particular emphasis on how virtues related to food waste practices have manifested themselves in agrarian and mature consumer society.

As a societal and ethical issue, food waste refers to food institutions, business sectors and consumers' duties and responsibilities. Extant academic food waste research has addressed the 
problem in relation to corporate social responsibility (CSR), e.g., Devin and Richards’ (2018) research indicating that sustainable practices often are conducted for the sake of CSR reporting, rather than for moral reasons. Likewise, food waste responsibility in the productionconsumption system has been examined (Welch, Swaffield, \& Evans, 2018), including analysis of institutional norms and rules' roles in food ecosystems, spotlighting the existence of ethical issues inherent in food waste and food waste prevention (Baron, Patterson, Maull, \& Warnaby, 2018). The issue of food waste is also connected inherently with societal values and ideals, but ethical principles such as values and virtues as guidelines to behaviour have been rarely discussed in extant literature. To suggest ideas on how to understand and deal with the food waste problem, it is necessary to analyse food waste as a societal problem, in addition to a consumption phenomenon. Examining virtues, as well as the values linked to them, and practices through which virtues are enacted, can provide important insights and justifications for making food waste avoidance a viable goal.

While virtues have been discussed broadly in extant philosophical-ethics literature, we draw on the Aristotelian view, which regards virtues as personal characteristics and traits that lead a person to adopt good practices that become inherent behaviours in all situations (Airaksinen, 1993, p. 230). The virtue ethics perspective allows us to broaden the ethical discussion around food waste beyond social responsibility reporting and food chain actors' functional roles and practices. In the present study, we analysed media texts from Finland covering two time periods, agrarian society (1885-1917) and mature consumer society (2008-2017), to examine understanding of food waste and these periods’ parallels and divergences in this regard. The study uncovers how ethical principles can underpin our understanding of the food waste phenomenon and how virtues that food chain actors assume can guide their practices toward more sustainable ways of handling excess food. This approach contributes to understanding of food waste by showing how traditional, deep-rooted conceptions and assumptions about 
standards of excellence, i.e., what is considered good or bad, underlie the ways in which excess food has been discussed during different time periods and what kinds of solutions are offered to deal with the problem. Many of the agrarian conceptions observed in the present study also underlie moral discussions on food waste today. However, new food waste themes have emerged as modern technology, innovative business models and empowered consumers have created novel solutions to food waste.

This article is structured as follows. First, we review extant literature on ethical principles and especially virtue ethics. After that, we discuss the manifestation of virtue ethics in food waste management in the food chain. We then present our empirical data collection and analysis procedures. Subsequently, we explore and discuss the themes describing food waste in different time periods. Finally, the chapter concludes with a discussion of how new insights gained by applying virtues rooted in ethics provide the foundation for developing and implementing food waste prevention policies and practices in food chain actors’ daily lives.

\section{Conceptual framework}

\section{Virtue ethics in classical ethical theories}

We draw our reasoning concerning the role of virtues in food waste from extant literature on business ethics, which has recognised and discussed various ethical approaches, such as deontological (duty-based), utilitarian, contract-based and virtue ethics (Kamtekar, 2004; Velasquez, 1998). Traditional virtues, such as gratitude, friendliness, forgiveness, mercy and love, are values to which people always will aspire. The virtue ethics perspective offers a practical approach to applying philosophical principles to everyday problems, such as food namely, how common virtues are connected to the food waste problem and its solutions (Solomon, 2003). 
Classical ethical theories - e.g., Platonism, Aristotelianism and Stoicism - are valueobjectivistic and teleological. They are based on the view that human actions are intentional and that a person makes decisions to reach goals. Virtue ethics derives from teleological ethical theory, which considers values from a teleological perspective, i.e., human actions' ends are the most important. Thus, it is a branch of value ethics. Consequences of actions are stressed when evaluating whether an act or rule is good or bad (Juurikkala, 2012). Virtue ethics shifts the analytical emphasis away from rule-based decision-making (deontological ethics) or consequences of actions (e.g., utilitarianism) toward the ethics of individuals and human character. For example, where a utilitarian would argue that giving to charity maximises societal well-being, and a deontologist would argue that we have a duty to help others, a virtue ethicist would point to the fact that helping others displays desirable virtues, such as being charitable or benevolent. Other desirable virtues include honesty, courage, friendship, mercy, loyalty, modesty and patience. (e.g., Brandt, 1959, p. 470).

Duty ethics (e.g., Kantianism), the second major ethics theory, differs from teleological virtue ethics. We can say that a duty to do something is a more demanding term or order than a wish to be a virtuous person. Virtue is more like a good-minded feature by its nature, and virtue ethics offers a hopeful line of action, instead of strict rules inherent in duty ethics. Value ethics assumes that value is a basic term to obey and seek. For example, happiness is a value to seek, but is happiness a virtue? Not necessarily. Whereas virtues can be values, like honesty, all values are not virtues. However, it is clear that overlap exists among values, virtues and vices, understood as empirical phenomena. Moreover, our conventional language usage often confuses these terms' meanings (Takala, 2012).

No simple way to classify all virtues exists. We suggest, based on Velasquez (1998, p. 138), that some dispositions can be classified as 'instrumental virtues', which enable people to pursue their goals effectively as individuals (e.g., persistence, carefulness, determination, 
transparency) or as part of a group (e.g., cooperativeness). Other virtues are 'non-instrumental' because they are desirable for their own sake (e.g., integrity, fairness, trust, respect, empathy, benevolence), i.e., basic virtues (Takala, 2012, p. 58). Some virtues are cognitive and comprise understanding moral requirements for ourselves and others. All humans need to maintain common trust, which is regarded as a basic value of human life and, thus, a basic virtue. The virtue of integrity refers to a set of features that an individual may possess; thus, it is the quality of being honest and having strong moral principles (Juurikkala, 2012). It is a personal choice to hold oneself to standards consistently (Harman, 1999). The virtue of benevolence inclines one to maximise people's happiness. The virtue of respect for others inclines one to exercise consideration for individuals' rights. The virtue of fairness inclines one to behave according to the principles of justice, and the virtue of empathy inclines one to live up to tenets of care (Velasquez, 1998, p. 138).

Theories that elaborate further on virtue ethics include Aristotelian classic virtues (Aristotle, 1981), MacIntyre’s (1981) 'after virtue’ thinking and various classifications concerning professional virtues (Brandt, 1959; Dent, 1984; Foot, 1978; Solomon, 2004) and business virtues (Velasquez, 1998). Importantly, MacIntyre recommends applying the Aristotelian virtue of aiming to realise proper goals in life. Finally, one traditional virtue can be recognised that is common to all people: integrity (Airaksinen, 1993, p. 249; Solomon, 2003).

Virtue ethics looks at moral issues from a different perspective than action-based ethics that concerns individuals' actions instead of moral rules. However, virtue ethics' conclusions will not differ radically from those of action-based ethics. Some virtues are correlated with utilitarianism (e.g., benevolence), rights (e.g., respect), justice and caring. Thus, instead of replacing other streams of ethics, virtues provide an additional perspective to, for example, Kantianism or utilitarianism (Juurikkala, 2012; Velasquez, 1998). 
Virtue ethics theory provides a criterion for evaluating consumers and business actors' actions, as well as social institutions and practices. For example, we can pose arguments that some economic institutions make people greedy, that large bureaucratic organisations make people less responsible and that some corporations do not treat their customers fairly. All such arguments evaluate institutions and practices on the basis of the theory of virtues. These arguments concerning organisations appeal to the idea that institutions are defective morally when they tend to form ethically acceptable practices (Alzola, 2017; Velasquez 1998).

In common business realms, institutional (ideal) virtues can be quite similar to those expressed in ordinary people’s everyday lives. Good business behaviour, benevolence, integrity and respect for stakeholders are all present in ideal business practices. However, a business goal to make more and more profit could lead to vices, rather than virtuous behaviour. The important characteristic of virtues is that they are learned entities and are a kind of 'automatic' feature in an acting subject. Regarding food waste, this means that avoiding waste generating actions and practices should be 'in the backbone' of the acting subject. Thus, virtues surface automatically in consumption situations, so avoiding waste does not require case-by-case reflection. This concerns both individuals and institutions (Airaksinen, 1993).

\section{Virtue ethics in food waste management.}

Food chain actors' waste-management practices.

One way to consider food waste is to contemplate food waste management practices in food chain organisations and consumers' everyday lives. Food waste reduction is a strategic issue within many retail chains that have established systematic food waste management practices and effective procedures. For example, food loss is monitored and registered regularly at the wasted item level (Finnish Grocery Trade Association, 2018; Katajajuuri, Silvennoinen, Hartikainen, Heikkilä, \& Reinikainen 2014). Retailers are committed to effective actions for 
economic reasons (Devin \& Richards, 2018), but also to enhance their reputations in sustainability and corporate social responsibility (CSR). However, the food waste problem in retail remains significant and requires further actions in various countries (Filimonau \& Gherbin, 2017).

The food-service sector entails business enterprises and public and private institutions preparing and serving food and meals outside consumers' homes. These institutions have diverse goals and their own reasons for and sources of waste, e.g., technical issues, legislation, practical reasons, misinformation and communication problems, and organisational culture (Heikkilä, Reinikainen, Katajajuuri, Silvennoinen, \& Hartikainen, 2016). Public-service organisations that prepare and serve food often are concerned about healthy diets, care, education and culture. Conversely, organisations following a business strategy aim to meet customers' needs and expectations to achieve customer satisfaction and outdo competitors. Customers seeking green options require timely and accurate information about sustainable options (Heikkilä et al., 2016). An organisation’s adopted business model embraces the goals, ideologies, values and practices that are connected to the creation and management of food waste. Thus, the business model can be founded on practices that utilise food waste instead of those that create it. Virtues and values that an organisation adopts guide sustainable practices aimed at food waste reduction. Moreover, households interact with upstream food chain actors, retail stores and food-service organisations. This interaction provides opportunities to participate in mutual practices, as retailers and food-service organisations provide service settings and encounters in which consumers purchase food and participate in everyday dining outside the home.

Given that food management practices are crucial to solving the food waste problem, the societal view that this chapter adopts considers virtues interconnected with practices. Research fields such as business ethics, ethical consumption and sustainable consumption have 
addressed ethical virtues as standards that guide consumers and organisations in pursuing moral values and sustainable goals in their everyday practices. Virtue ethics highlights the focal role of practices that a person may adopt not only for the sake of the practices themselves, but also to develop virtues and eventually to be a good person. Essentially, practices involve standards of excellence that indicate what behaviours are considered good or bad (Garcia-Ruiz \& Rodriguez-Lluesma, 2017). Thus, practices can be virtuous in character, or serve as context and occasion for virtue development.

Virtues in food waste management.

The virtue ethics approach connects the problem of food waste to deeply-rooted societal values and norms. Extant food waste literature so far has not addressed virtues' role in solving the food waste problem, though several articles have discussed the topic on a broader level, e.g., virtues in CSR and businesses sustainability (e.g. Becker, 2017; Devin \& Richards, 2018; Ketola, 2017).

Virtues can be considered worthy of aspiring to and useful when setting standards for performance excellence to prevent food waste. In trying to realise sustainable values (Becker, 2017), consumers may develop virtuous practices (Garcia-Ruiz \& Rodriguez-Lluesma, 2017). Consumption practices are domain-related. Every practice involves standards of excellence, which serve to identify what counts as good or bad. Thus, virtuous goals guide consumption as practice - goals that depend on principal practices' internal goodness, with which those practices interlock. In the context of reducing food waste, this means that those standards also must be set up in every food-producing/processing practice in the food chain to ensure that food is used or recycled. Some virtues are needed in any practice, e.g., integrity, whereas others seem particularly unique to consumption, e.g., frugality, moderation and simplicity (GarciaRuiz \& Rodriguez-Lluesma, 2017). Moderation is the ability to use resources proportionately 
in ways that befit the standards that the practice imposes on consumption acts. Frugality and simplicity have been important virtues, e.g., in agrarian society, in which material resources are scarce. A virtuous consumer is economical regarding money and materials, with saving and self-sufficiency being valuable goals (Heinonen \& Autio, 2013). To pursue these goals, a consumer needs practical wisdom, which is a mindful habit through which one is excellent in each case at judging available means to accomplish a worthy goal.

A contradiction can exist between the idea of ethical virtues and food chain members' goals, decisions and behaviours. Consumption has been disparaged amply by academics and public opinion alike allegedly for being a source of materialism, hedonism and bad taste, among other personal and social maladies (e.g., Kozinets \& Handelman, 2004). Considering these potentially harmful effects from consumption, we complement this view by arguing that consumption also can become a context in which people improve themselves ethically. In studying ethical consumption, scholars have focussed on special-interest groups - such as fairtrade enthusiasts, eco-village dwellers and boycotters - and the moral dilemmas that those consumers face, e.g., concerning "the right” choices to make (e.g., Hong \& Handan, 2016). Virtue ethics adds to this the question of the consumer's and food chain actors' character development, e.g., what kind of moral person one wants to be (Garcia-Ruiz \& RodriguezLluesma, 2017).

Virtues are developed through practices, which can be regarded as important sustainability skills. Food waste reduction practices interrelated with virtues could become a moral code and habit that will pave the way to better morals for mankind. Food waste management requires such behaviour among workers, management and consumers. Professional skills - such as care, meticulousness and the ability to follow instructions - are, in a way, standards of excellence in professional practices. 
Furthermore, while providing healthy food and appropriate diets for people, the canteens could control food waste not only for diners (Ferreira, Martins, \& Rocha, 2013), but also together with diners. This way, consumers cultivate the skills needed to behave in a manner that minimises food waste while dining. This kind of cooperation could generate virtues such as respect and benevolence, resulting in mutual benefits. Finally, the retail and food-service sectors serve people belonging to different generations, from day-care centres to retirement homes, so they are in a position to practise common values and virtues with an broad crosssection of people.

\section{Methodology and data}

Newspaper articles disseminate information about societal norms and values, and they contain themes that describe the social order of people and organisations in everyday life (Pietilä, 1976). We expect that media publicity may help widen awareness of food waste phenomena among consumers, business managers and public-policy makers (Takala, 1989). Discussions and debates concerning various phenomena around food practices can be found in different time periods' news media. Therefore, we decided to collect empirical data from newspapers and magazines, reflecting societal themes that underlie values, virtues and practices related to food waste. We expected the data to give us insights on the virtues that are viable in terms of enacting them into food waste practices.

Since food waste generation and handling are rooted to households practices in consumers' daily lives (Evans, 2011), we expected the theme to have deep roots in Finnish culture. Indeed, during various time periods in Finnish history, excess food raised many questions and debates about the right solutions. The first dataset covering the years 1885-1917 was collected from the Digital Archives of the National Archives of Finland. The search term 'food leftovers' was applied to retrieve articles from the digital archive of Finnish newspapers and magazines. This 
data disclosed food waste issues that arose in an agrarian, self-sufficient, and poor society. Finland was a Grand Duchy of Russia that became an independent nation in 1917. During this time period, important governmental structures and societal institutions were being created, but elements of a consumer society remained absent (Heinonen \& Autio, 2013, p. 47). Agriculture, raising cattle and forestry were the major branches of industry, and $87 \%$ of the population lived in rural areas (Heinonen, 1998; Heinonen \& Autio, 2013, p. 52). Many changes gradually took place in society, such as the emergence of a monetary system, freedom of trade and retail shops in the countryside (Heinonen, 1998, p. 49). Hard work was the lifeline for people struggling to produce food and survive harsh conditions, with the ever-present threat of bad harvests. This period is described aptly as a time of scarcity. The importance of self-sufficiency and saving money, avoiding needless and unnecessary consumption, and minimising waste were important everyday practices. (Heinonen \& Autio, 2013). Notably, public enlightenment and popular education were provided widely and considered important even in the 19th century (Heinonen, 1998). We refer to this period as the agrarian society.

The dataset encompassing the years 2008-2017 was collected using three different variations of the search words 'food waste' from the digital archive of the largest Finnish newspaper, Helsingin Sanomat. Arising out of its contemporary stage of escalation, food waste problems have been addressed frequently in media texts for the past decade. The texts reflect food waste issues during a modern period, which we refer to as the mature consumer society (Heinonen \& Autio, 2013, p. 59). Most people in Finland during this period lived in urban areas or small rural towns, with services comprising the principal engine of industry. Public education and the availability of free media, technology and information, as well as money and credit, allow consumers to gain and use resources, and live in abundance. Food chain operations have been separated, with food supply and demand functions allocated to different actors. Thus, 
specialised skills and professions in food production and delivery have been refined, and the food chain has become highly efficient.

[Insert Table 1 about here]

The data searches resulted in 26 articles reflecting agrarian society (1885-1917) and 199 articles describing mature consumer society (2008-2017) (see Table 1). A qualitative contentanalysis technique (Eriksson \& Kovalainen, 2016) was applied during data analysis. The textual datasets first were read and coded according to meanings, practices and values related to food waste. The coding categories were developed during interactions with the data, and the interpretation of the text was developed based on a close reading of the text (Spiggle, 1994). This analysis method allowed us to produce a deep understanding of food waste as a phenomenon connected to the societal context (Hsieh \& Shannon, 2005).

\section{Themes and virtues of food waste during different periods}

\section{Virtues as guidelines for food chain actors’ practices.}

A common feature across the data samples is the persistence of rules and norms regarding food behaviour. A distinct phenomenon in the agrarian-society data is moral blaming, which seems to refer to explicit and directive norms and rules that urge people to be particularly careful with handling food waste. Although moral blaming focuses on the negative, the theme contains moral messages that aim to do good in the community. It partly originates from the threat of food contamination, which is less of a threat in mature consumer society, though it still exists (Porpino, 2016). For example, contemporary retail food chains prioritise food security in their food waste management (Finnish Grocery Trade Association, 2018). These measures reflect virtues of trust and transparency. In agrarian-society data, giving leftovers to the poor appeared to be a norm. Donating excess food to charity in a mature consumer society is viewed in retail 
stores as a way to help disadvantaged people - an opportunity for mercy. Thus, the virtue of benevolence is present in both time periods.

The media texts from these two very different time periods consistently contain ethical tones that reflect moral virtues that people should internalise. It is pointed out frequently that individuals have a moral duty to minimise waste, as waste signals carelessness and a lack of discipline in a household - vices that constitute a threat to desirable behaviour.

Both datasets point to the adoption of various virtues that are specific to the consumption domain. For example, it is common to describe a housewife as resourceful and frugal, connoting the virtue of thriftiness. However, sometimes benevolence as a virtue can lead to overusing food. Overprovisioning and abundance of food, for example, are acts indicating care and 'good mother' behaviour that drives to food wastage in certain cultural as sociodemographic contexts (Porpino, 2016).

The basic virtues of integrity, fairness, trust, respect, transparency and benevolence can be identified as guiding principles in food chain actors' policies and practices in handling excess food. In addition, domain-specific virtues prevail in different societies. Because diverse virtues exist, people and organisations should explore and decide which virtues are appropriate for their goals, values and resources in different situations. A common feature of all virtues is that they are directed toward the societal well-being and aim to do good for the community (Velasquez, 1998). Next, we reflect on what these virtues could mean in food chain actors' daily practices and present examples based on the empirical data.

\section{Food waste themes in agrarian society.}

The themes in the data from the 1885-1917 period reflect issues and concerns connected with the life and conditions of Finnish agrarian society. The term 'food waste' did not appear in the 
agrarian period data. Because excess amounts of food did not exist, food was not wasted, i.e., all was consumed, used and eventually fully exploited in households. Instead of food waste, the discussion focused on food leftovers. The analysis revealed three themes on food leftovers that reflect Finnish agrarian society's values and virtues.

\section{1) Meticulous rules in handling excess food}

The data indicate the importance of adopting systematic practices, instructions and directions in processing excess food. Order and caution in food practices are presented as opposites to wasting food or throwing it away. The methodical utilisation of leftover food means economising and conserving: Instructions are given on how to sort the leftovers into different types to facilitate future use. The sensible use of leftovers and various methods of reusing food are esteemed skills that are necessary to avoid waste. The data include a wide array of positive, encouraging ideas on reusing everything, making use of available resources and evaluating their suitability for reuse. These meticulous rules refer to the virtue of frugality, and a respect for food.

Meticulousness is required because of hygiene, diseases and disorders associated with leftover food. Accordingly, leftover food is susceptible to contamination and thereby regarded as a threat that can transmit severe diseases. Rules, instructions and warnings for handling leftovers are provided in the magazines and newspapers of this era. Furthermore, leftovers represent mess and disorder in the house, thereby signalling uncleanliness attributed to housewife characteristics. Signs of moral blaming and avoiding vices can be seen, by which ordinary people are reproached over a lack of tidiness and unwanted habits that they follow in their daily lives.

People living in scarcity constantly avoid waste in their everyday lives. Correspondingly, food leftovers are not regarded as waste, and respect for leftovers helps people survive. Conversely, 
wasted food is connected to a lack of respect for resources, typical of 'the Western way of life'. The careful usage of leftovers denotes avoidance of waste, while people inevitably depend on food leftovers. Although the rules provided to consumers are meticulous, they reflect an ideal of meticulous and simple living. The following data quotes illustrate these ideals:

“Leftovers. Do not throw away any leftover food. All can be used if you are meticulous. Stale pieces of bread can be softened in steam or cold water, and if you put them in the oven for a while, they taste very good”. 01.03.1911 Emäntälehti: Martta-yhdistyksen äänenkannattaja no 3-4

“I organise the usage of leftover food by writing in my menu about each day’s breakfast dish: "leftovers from the previous day’s dinner" either "warmed”, "fried" or renewed in some other way, depending naturally on each housewife's tastes. Even if you can assume there are no leftovers, I still write down that "leftovers from the previous day's dinner” and additionally the name of some other dish. If you see that this note about the previous day's dish is omitted, leftover food is left in the cupboard, or they go in the slop bucket. A further benefit of using "leftovers from the previous day's dinner” as a breakfast dish is that in that way, fuel is saved. Renewing a done food, you do not spend anywhere near as much gas or wood as cooking a totally new dish”. 02.04.1917 Suomen nainen no 7

2) Mercy put into practice: Food leftovers used for charity

Leftover food is a resource that can be used to help people in need of the basics, including food. It provides those who possess food with an opportunity to show mercy on the poor, which can allude to religious practices such as pardon. Nursing other people and animals implies caring for them - notably, the virtues of fairness and benevolence. 
Leftovers frequently are connected to benevolence, nurturing and caring for domestic animals. Instructions are given on how to prepare animal food from leftovers. The diligent use of leftovers shows caring for animals, along with frugality: the skill of saving money. The following quotes show that mercy toward poor people or defenceless birds gets religious tones:

“He who grants an amnesty on poor people lends to the Lord ... I have seen with my own eyes how young men groped their hands in a pot, in which wash water from a food container had been poured in the hopes that they would find some leftover food in it. Meanwhile, the house folks were having their meals. They begged for potato peelings and heads of herring, which they ate with grateful minds”. 03.06.1913 Paimen-sanomia: evankelinen kuukausilehti

“So, there are many of us, but sometimes in winter, we remember them! I can’t be wrong in thinking that you readers, at least sometimes in winter, sprinkle hulled grain or leftover food on the yard for small birds to eat. ... you cannot believe how good you feel when you give from your heart. ...A merciful person is rich”. 01.01.1903 Tuulikki no 12

\section{3) Uncovered societal hierarchies}

Endemic poverty and scarcity in society led people to gather and conserve excess food. The hierarchy between the haves and have-nots is visible through leftover food handling. A common perspective is that leftovers obviously are something to be given to servants or others considered lower in societal class. Meanwhile, in making these hierarchies visible, leftovers sometimes are connected with begging, which carries a negative stigma visible in comments such as: 'begging forbidden by the law'. Thus, leftovers are connected with mendacity. In the following quotes, the hierarchical positions of not only masters and servants, but also the status differences between the rich, the poor, and domestic animals are visible: 
“The housemaids must bolt down cold food leftovers stading up, after the master and mistress first have their meal and the quarter is located in the kitchen...” 01.01.1900 Uuden ajan kynnyksellä : Suomen työväen alpumi no 3

“About using leftover food. In everyday households, it is very important to be able to create tasty meals using leftover food. ... a rich person behaves incorrectly when throwing away something that is still worth eating, although he would feel his means justified this kind of conduct. Similarly, a poor person is wrong if he shows wastefulness in such a manner. Where either cats, dogs or pigs are kept, part of the household waste ends up to their benefit, i.e., food ...” 01.09.1906 Pellervo no 9

\section{Food waste themes in mature consumer society.}

The amount of food waste has been on the increase in mature consumer society, and consequently, it has become a burning question with a global reach and a contradictory character. While waste is generated because of abundance, in this era, a remarkable number of people live with food scarcity. Several food waste themes persist in society, and some themes resemble the data from the agrarian era. However, as the waste problem has expanded, the utilisation and reuse of excess food has become a source of innovation in contemporary living among consumers and companies' business models. Modern technology has enabled many of these innovations to combat food waste.

Actors in the food distribution chain recognise the food waste problem. We identified several themes and stories in the data, in which one or more precious virtues appeared to underlie food chain actors' thoughts and practices. However, sometimes a virtue actually was discussed in terms of its absence, e.g., a case in which distrust prevails between actors. Another breach stems from the challenges from acting out various virtues. Because virtues reflect a high level of ethics (Velasquez, 1998), they can be regarded as idealistic, given the pragmatic goals and 
limited resources and skills of households and organisations in the food chain. For example, lack of awareness or time resources, or insufficient skills and education, impede the actualisation of virtues.

1) Food waste is a global threat to mankind

Various large-scale global issues are addressed in the data when describing the food waste problem's scope. The ultimate vision is that mankind's downfall will result if climate change is not controlled. Solutions proposed range from strict rules and legislation to small proenvironmental acts easily carried out in everyday life. Accordingly, sustainable consumption is to be set as the guiding principle that can be carried out either by following rules and legislation or realising that reducing food waste is one practice that anybody can do. The latter course of action means that the food waste problem denotes the achievement of fundamental virtues, such as integrity and fairness. The following data quotes portray the contradictory nature of food waste problem and show the ways how solutions are provided:

“Almost a billion people are starving. Meanwhile, food is produced more than ever, and millions of tons are thrown away every year”. HS 27.2.2011

“Food production causes 26 percent of the global ecological footprint. It can be reduced, among other things, by reducing meat consumption and food waste”. HS 5.8.2017

“The appeal that scholars made worrying about the future of mankind lists 13 examples of issues that mankind could do in order to achieve sustainability and avoid destruction”. HS 14.11.2017

2) Food waste can help mitigate social problems 
Food waste is viewed as a way to address social problems such as poverty and scarcity. Several initiatives and programmes have been established in which excess food generated in foodservice institutions, kitchens and retail stores is distributed to disadvantaged people. A controversial aspect is that food waste donations are viewed predominantly as a way to reduce food waste, rather than as a solution to mitigate the fundamental problem of people in need, as poverty leads to exclusion from mainstream society.

Food banks, charities, retailers and restaurants have exhibited practices aligned with integrity and fairness. Consumers and organisations aim to show benevolence by donating excess food, but they also create negative associations because 'breadlines' are viewed as a stigmatising mechanism. Thus, these arguments reflect a desire for fairness. Some newspaper articles demand solutions and fairness by stressing the importance of developing new business models to solve the food waste problem, or appealing to fairness when advising households not to throw away so much excess food.

Trust has a well-recognised position as a cornerstone of business relationships (Morgan \& Hunt, 1994), although it rarely is mentioned as a virtue. Some articles mentioned the importance of state and municipal authorities in ensuring trust in the context of handling food waste. Nonetheless, voluntary food-sharing mechanisms are considered inevitable when organising leftover food distribution to the disadvantaged in society. Instead of trust, it seems that distrust has formed between those in need of donated food and the Finnish authorities and other official organisations. The following quotes portray examples of this distrust towards mitigating social problems through bread lines:

"In the bread line, one has to stand humble and obedient. In the world, there are social supermarkets where one can search for aid without drawing attention. There is a 
danger that a permanent market for the poor arises.... The line is an important symbol, but it is not a solution”. HS 2.4.2017

"Members of Parliament want to change food legislation so that edible food that is removed from the marketplace would go to distribution or other utilisation. ... this initiative is not about lending a hand to address poverty; politics should intervene poverty. But it is mindless to throw away food while there are people in need”. HS 25.5.2016

3) Food waste as a resource in consumer lifestyles

Food waste studies rarely have considered the phenomenon from the perspective of consumer lifestyles (Aschenann-Witzel et al., 2018). Our data indicate that such a connection exists and that virtues play a role in them.

Households and other food chain actors often are blamed for overconsumption and wasting edible food, which shows disrespect. Respect and disrespect often are present simultaneously in accounts. For example, although food-service institutions waste massive amounts of food, they express respect as they profess having a mission to educate children to value food. Furthermore, transparency appears to be present due to regulations concerning food safety and hygiene.

While retail stores regard food waste reduction as a strategic issue (Devin \& Richards, 2018), and they have achieved remarkable improvements in practices, e.g., in logistics and the recycling of waste (Katajajuuri et al., 2014), retail stores' approach to consumers features critical areas in which further improvements might be possible. A case in point is providing food options in appropriate portions for different types of consumers and households. Smaller 
package sizes suitable for small households and sustainability-oriented consumers have been launched in recent years. Thus, packaging can support virtuous practices among food chain actors, as suggested in the following:

“Rational packaging reduces food waste ... Properly packaged products keep for a long time and survive transport well”. HS 7.8.2017

Although food waste usually is addressed merely as a problematic issue, and clearly is something bad to a great extent, the present study's data raise the prospect of new opportunities and possible solutions, in addition to threats. For example, food waste is portrayed as part of a fashionable consumer lifestyle. The data indicate that young hipsters, often living in urban areas, consider it 'cool' to eat leftover food that restaurants, private households or various institutional kitchens generate. The concept of hipsters in our data represents a trendy lifestyle, i.e., values, attitudes, knowledge and behaviour that characterise certain trendsetters' consumption choices, i.e., those who are enthusiastic about fashionable movements and styles. Marketers are interested in hipsters as forerunners guiding the way to new trends and styles in urban culture (Arsel \& Thompson, 2011), and restaurants preparing meals from excess food are part of a contemporary trend that involves hipsters, an appealing target group. Freegan Pony, for example, conveys the ideology of sustainability by disapproving the act of throwing away food and endorsing the use of food waste in cooking. This food waste restaurant aims to instruct people about food waste by offering pleasurable meal experiences and bringing different people together. The following data quotes illustrate new opportunities and trends in food waste, also reflecting a potential for defining new virtues:

"In Paris, one can have a three-course dinner in the first food waste restaurant of the world. ... Freegan Pony restaurant advertises itself as the world’s first waste restaurant ... serving dinners made of food waste with a volunteer staff. One may 
pay for the dinner what one wants. .. the idea of the restaurant is to enlighten people about food waste through experience and to bring together different people ... Hipster groups, parents with kids and dating couples are sitting at the tables”. HS 2.4.2016

“Utilising food waste has rapidly become a global phenomenon. ... Leftover food is predicted to become this year's food trend. ... Food waste already is competing in a business sense. In Finland, there are already three applications to supply restaurants’ leftover meals, and the developers currently are arguing with each other about who was the first to invent the idea”. HS 9.3.2016

“This bar makes drinks out of rubbish; they even recycle lime slices - ecological restaurants and waste food are trends in the world, and now they found their way to Finland”. HS 19.5.2017

The food waste challenge can be viewed as a game - flirting with poverty and making some kind of art from scarcity. Such challenges tend to seize topical debates and jump onto trends in food culture, with people testing whether the trend is feasible and would serve as a possible way of life. Furthermore, lifestyle offers an apt proving ground for adopting food waste as a trendy upscale dining alternative (see Thompson \& Coskuner-Balli, 2007, for a similar discussion of eco-food).

4) Counselling and instructing people and novel services: normative guidelines and practical tools to reduce food waste

One common theme across the datasets from different periods is the tendency to guide and advise people and organisations on how to reduce food waste. This is understandable in light of the food waste conceived as an ethically and economically negative phenomenon that should 
be combatted. The agrarian period data contains meticulous rules that guide people to not only respect food, but also carefully use food like a scarce resource. Media research on mature consumer society indicates an agenda of providing useful advice and guidelines to help empower and enlighten people to handle the abundant amounts of food, thereby changing their food habits, including general consumption behaviours, toward more sustainable levels. The versatility of the possible virtuous food practices is illustrated by the following data quotes:

"If a single person does not want to eat the same food for four days in a row, half the portion has to be frozen immediately. ... Alongside the Marthas, the Finnish Consumer Union, ... WWF and S-group give tips on reducing food waste. ... as do libraries and parental clinics, HSY delivers small cards with recipes for leftover dishes and tips for reducing food waste”. HS 3.3.2013

“Take photographs of your fridge - five tips for cutting food waste”. HS 21.3.2014

\section{Food waste virtues in agrarian and mature consumer society.}

Many of the newspaper and magazine texts from different time periods refer to food leftovers and food waste directly, or they indirectly assume that the waste problem is attributable to consumers' shopping, cooking, dining and general food handling practices and skills. Thus, although the role of institutions' structures and practices also is acknowledged, the principal responsibility is placed on consumers (e.g., Chatzidakis, Shaw, \& Allen, 2018; Welch et al., 2018). Meanwhile, the moral discourse on the food waste problem's consequences addresses global concerns, such as climate change and the planet's sustainability. The empirical data illustrate the multiple ways in which societal norms and habits guide consumers and other actors, or in which scarcity dictates necessities. 
Table 2 describes how food waste themes have changed and how these changes reflect societal aspects and concerns in agrarian and mature consumer societies. The focus has shifted from individuals, households and communities toward considering food waste as an issue of sustainability in large societies and in the global sphere. Different virtues can be viewed as underlying the themes; thus, not only have societal themes changed, but the desired characteristics of people or standards of excellence underlying these themes also have changed.

\section{[Insert Table 2 here]}

In agrarian society, food usually was prepared and consumed in a household. It was produced in people’s own gardens or in a nearby geographic location. Households were self-sufficient in producing and storing food, and domestic animals were common. Scarcity was a major aspect of food and food waste in this era. Thus, scarcity dictated many specific consumption virtues such as frugality, simplicity and moderation that guided food practices, i.e., reasonable food preparation and innovative reuse of excess food in households. Risks from food storage frequently were addressed, e.g., the threat of contamination and diseases. This illustrates the adoption of basic virtues such as care, benevolence, respect and transparency. The consumption-specific virtues of frugality, simplicity and moderation, as well as the basic virtues of benevolence and care, seem to underlie the beneficial usage of leftover food to feed animals and other people.

In mature consumer society, people live with abundance. Consumers and households can afford to waste food without even noticing it. However, awareness of the negative consequences of food waste has been raised on a global scale, reflecting the virtues of respect, fairness and benevolence. The amount of food waste generated in the food chain raises questions about whether standards of excellence exist, and whether vices are guiding food chain practices rather than virtues. Nevertheless, retailers, as important food chain actors, prioritise food waste 
management as part of their corporate responsibility programmes, as well as for economic and efficiency reasons. The concern over inequality reflects the virtues of fairness, respect and benevolence. In mature consumer society, food waste is not only a problem, but also a solution, as it is capitalised on as a business resource. Indeed, innovative business models have been created, and mobile apps like ResQ, Lunchie and Matsmart have been launched quickly and adopted by pioneer consumer groups. The virtue of trust underlies use of these apps, providing a platform through which restaurants can sell excess food on short notice, usually at a reduced price, and consumers can locate places where food is available and place orders. In mature consumer society, resources are abundant, but there seems to be a call for a set of virtues guiding people toward realising positive and desirable characteristics that should drive their behaviour.

\section{Discussion}

\section{Changing food waste practices and virtues.}

This chapter applied a socio-philosophical perspective to the food waste problem and suggested that virtue ethics can be applied to understand deep societal values, virtues and practices that foster food waste reduction. Analysis of media articles has disclosed food waste themes and virtues that underlie public debates in different time periods. This study contributes to the understanding of food waste management by illustrating how ethical virtues as standards of excellence are interlocked with food practices. As the societal themes of food waste are changing, virtues and food practices are changing as well. In agrarian society, leftover food was managed in households, whereas in mature consumer society, food waste is a problem that affects various functions and actors across the entire food chain and society. In agrarian society, traditional, consumption-specific virtues such as frugality, simplicity and moderation propelled the use of exemplary food-handling practices. Conversely, in mature consumer society, 
universal, basic virtues appear to be lacking in prevailing practices. This study also add understanding of food practices, namely that food practices often lack standards of excellence, i.e., virtues are absent from these practices. Sometimes practices are based on vices rather than virtues. This highlights the need to scrutinise food practices and identify possible violations of excellent standards. Thus, a defined list of virtues for food waste management can help food chain actors to detect vices and incorporate virtues to food practices.

This study contributes understanding of food waste as societal issue. Changing food waste themes can be seen to reflect a societal shift from gemeinschaft to gesellschaft, i.e., the transformation from a rural existence to urbanisation, as described by sociologist Tönnies. His first book, Gemeinschaft und Gesellschaft, published in 1887, analysed the gemeinschaftgesellschaft distinction. While gemeinschaft concerns the community, and gesellschaft concerns society, the basic idea was to introduce the two fundamental methods of associating the communal with the societal. If this association is valuable and a goal in itself, it is a communal consortium, i.e., the gemeinschaft relationship. Conversely, if the interconnection is merely instrumental, it will result in transmitted or instrumental gesellschaft relationships. The values and virtues typical of gemeinschaft such as frugality, simplicity and moderation are seldom visible in food practices of mature consumer society. Accordingly, strengthening these traditional virtues guiding food waste management could act as the glue that associates the communal with the societal.

Apart from outlining virtues or standards of excellence for food waste management, mentors and role models (Audi, 2010) are needed to enable food chain actors to recognise and practise exemplary actions. Furthermore, as virtues elicit good habits, they must be practised to become commonplace guidelines for desired behaviours (Murphy, Laczniak, \& Harris, 2017). Education and enlightenment have been dominant themes in the data, and these could be possible solutions to entrenching desirable practices. Likewise, consumer awareness of 
sustainability is created and renewed through ideologies, e.g., a worldwide overconsumption day to raise awareness creates an international communal spirit, and social media help nurture shared ideals and values. Inventive, common-sense practices were cultivated in agrarian society, when scarcity was a daily occurrence. Everyday virtues of thriftiness, rationality, communal spirit, innovativeness and low food consumption could be cherished and practised in mature consumer society to create a better future.

In mature consumer society, fashion and lifestyle, such as hipsterism, may foster an ideal to reduce food waste. Sociologist Georg Simmel theorised that when lower social classes adopt fashions/trends, the upper classes dismiss them, then adopt the same fashions/trends on their own terms (e.g., Simmel, 1957). Thus, trendy lifestyles with sustainable ideals could attract other groups who subsequently adopt these ideals in their own way. Bourdieu (1984) approached the phenomenon of fashion with similar ideas. Correspondingly, the middle classes in particular adopt certain trendy consumption practices aimed at combatting food waste. They do not adopt these practices for thriftiness, but to live by their ideals.

Although virtues as guidelines to nurture the common good are suggested as a viable mechanism to prompt food chain actors to pursue sustainable food management and consumption practices, public discourse has examined the optimal balance of excellence that one should seek (Airaksinen, 1993). Deficiencies in virtues may lead to vices and damage, whereas excessive pursuit of standards of excellence can result in intolerance of other people's behaviours or lifestyles (Murphy et al., 2017).

\section{How can virtues be enacted?}

Virtues are not innate, but learned and internalised. Unlike legislation, regulations or rules and norms that come from external sources, virtues are individuals, households and organisations' essential characteristics. Based on insights raised from empirical data and theoretical 
understanding on the nature of virtues, we make the following recommendations on how to act out virtues in everyday food behaviour to control and reduce food waste.

Using education to increase respect toward food. Skills in food practices in the food chain are among the most important and promising avenues for solving the food waste problem. Many food-service institutions aim to educate people on issues relating to food and have a platform to deal with the food waste issue as well. Professional skills in management, food service and retail practices have been improved, but could be improved further. Education that aims to affect consumers' values concerning food, attitudes toward dining and routines in shopping, cooking and food consumption is recommended. In terms of virtue ethics, respecting food as a precious resource is one key to food waste reduction.

Highlighting frugality as a virtue. Agrarian-society data indicated the importance of thrift and meticulousness in handling food, which was a precious resource in households during this period. Introducing the virtue of frugality to mature consumer society could raise awareness of food's value.

Promoting circularity, recycling and reuse as indicators of integrity and transparency. Recycling involves the idea that waste is the raw material of new products and services. The idea of reusing food is visible in agrarian-society data. It requires integrity and transparency for the sake of safety. Food recycling and reuse practices can be adopted at all levels of the food chain.

Promoting caring about the planet and other people as acts of benevolence. Donating food as a way to help people in need is addressed in both the agrarian and mature consumer society data. While in the agrarian period, it was an act of mercy to donate leftover food, in mature consumer society, wasting food is commonplace, with donations connected to the virtue of benevolence, although the fundamental motive of donating may be purely selfish. 
Integrity, trust and transparency should guide food-service institutions' practices. Legislation concerning food safety and societal and cultural norms regarding food production and consumption are governing retail sector and food-service institutions' food practices in particular, but they also affect households. While legislation and regulation with respect to food is necessary, one focal implication of virtue ethics is that people and institutions not only should follow the law and norms, but also pursue high ethical standards through the virtues of integrity, trust and transparency.

\section{Conclusions}

This paper has discussed the possibilities how ethical virtues can be applied in food chain actors’ food management practices. To conclude, we suggest the following solutions for reducing food waste:

- Identifying virtues that help foster food waste reduction in food chain organisations, with a particular emphasis on nurturing widespread public respect for these virtues.

- Advancing opportunities to practise such virtues and choose role models who enact behaviours that meet standards of excellence, and thus adopting moral codes of conduct based on virtues.

- $\quad$ Fostering the revival of traditional, simple, everyday-life virtues.

- Entrenching virtues as habits and routines in everyday practices and featuring values as integral aspects of fashionable consumption phenomena.

- $\quad$ Paying attention to practices that feed vices and incorporate virtues into them.

Acknowledgements: The authors thank Adjunct professor Maarit Knuuttila and M.Sc. Minna Oksanen for their valuable assistance in collecting the data used in this paper. 


\section{References}

Abdelradi, F. (2018). Food waste behaviour at the household level: A conceptual framework. Waste Management, 71, 485-493.

Airaksinen, T. (1993). Moraalifilosofia. Juva: WSOY.

Alzola, M (2017). Corporate Roles and Virtues. In A.J.G. Sison, G.R. Beabout, \& I. Ferrero A. (Eds.) Handbook of Virtue Ethics in Business and Management (47 -56). Dordrecht: Springer.

Aristotle, (1981). Nicomachean Ethics. London.

Arsel, Z. \& Thompson, C.J. (2011). Demythologizing consumption practices: How consumers protect their field-dependent identity investments from devaluing marketplace myths. Journal of Consumer Research, 37 (5), 791-806.

Aschenann-Witzel, J., de Hooge, I.E., Almli, V.L. \& Oostindjer, M. (2018). Fine-tuning the fight against food waste. Journal of Macromarketing, 38 (2), 168-184.

Audi, R. (2010). The place of ethical theory in business ethics. In G. Brenkert \& T.L. Beauchamp (Eds.) Oxford Handbook of Business Ethics (46 - 69). Oxford: Oxford University Press.

Baron, S., Patterson, A., Maull, R. \& Warnaby, G. (2018). Feed people first: A service ecosystem perspective on innovative food waste reduction. Journal of Service Research, 21(1), 135-150.

Becker, C.U. (2017). Social approach: Virtue ethics enabling sustainability ethics for business. In A.J.G. Sison, G.R. Beabout, \& I. Ferrero A. (Eds.) Handbook of Virtue Ethics in Business and Management (pp. 1383-1394). Dordrecht: Springer.

Bourdieu, P. (1984). Distinction :A Social Critique of the Judgement of Taste. Cambridge, MA: Harvard University Press

Brandt, R. (1959). Ethical Theory. New Jersey: Prentice Hall.

Chatzidakis, A., Shaw, D. \& Allen, M. (2018, May 4). A psycho-social approach to consumer ethics. Journal of Consumer Culture. DOI: https://doi.org/10.1177/1469540518773815

Dent, N.J.H. (1984). Moral Psychology of Virtues. Cambridge: Cambridge University Press.

Devin, B. \& Richards, C. (2018). Food waste, power, and corporate social responsibility in the Australian food supply chain. Journal of Business Ethics, 150 (1), 199-210.

Eriksson, P. \& Kovalainen, A. (2016). Qualitative Methods in Business Ethics. London: Sage. 
Evans, D. (2011). Blaming the consumer - once again: The social and material contexts of everyday food waste practices in some English households. Critical Public Health, 21 (4), 429-440

Ferreira, M., Martins, M.L. \& Rocha, A. (2013). Food waste as an index of food service quality. British Food Journal, 115 (11), 1628-1637.

Filimonau, V. \& Gherbin, A. (2017). An exploratory study of food waste management practices in the UK grocery retail sector. Journal of Cleaner Production, 167, 1184-1194.

Finnish Grocery Trade Association. (2018). Ruokahävikin vähentäminen kaupoissa. Retrieved from https://www.pty.fi/ruokahaevikki/. Accessed 28.5.2018

Foot, P. (1978). Virtues and Vices. Oxford: Oxford University Press.

Garcia-Ruiz P., Rodriguez-Lluesma C. (2017). Consumer behavior: Vices, virtues, and the search for the good life. In A.J.G. Sison, G.R. Beabout, \& I. Ferrero (Eds.) Handbook of Virtue Ethics in Business and Management (1067-1075). Dordrecht: Springer.

Harman, G. (1999). Moral philosophy meets social psychology: virtue ethics and the fundamental attribution error, Proceedings of the Aristotelian Society, 99 (3), 315-331.

Heikkilä, L., Reinikainen, A., Katajajuuri, J.M., Silvennoinen, K. \& Hartikainen, H. (2016). Elements affecting food waste in the food service sector. Waste Management, 56, 446-453.

Heinonen, V. \& Autio, M. (2013). The Finnish consumer mentality and ethos: In the intersection between East and West. In V. Heinonen \& M. Peltonen (Eds) Finnish Consumption! - An Emerging Consumer Society between East and West (pp. 42-85). Studia Historica 83. The Finnish Literature Society. Helsinki.

Heinonen, V. (1998). Talonpoikainen etiikka ja kulutuksen henki: Kotitalousneuvonnasta kuluttajapolitiikkaan 1900-luvun Suomessa (Peasant Ethic and the Spirit of Consumption: From Household Advising to Consumer Policy in 20th-century Finland). Bibliotheca Historica 33. Helsinki: Suomen Historiallinen Seura.

Hong, S. \& Handan, V. (2016). Re-imagining the utopian: Transformation of a sustainable lifestyle in ecovillages. Journal of Business Research, 69 (1) 120-136.

Hsieh, H.-F. \& Shannon, S.E. (2005) Three approaches to the qualitative content analysis. Qualitative Health Research, 15 (9), 1277-1288.

Juurikkala, O. (2012). Likeness to the divinity? Virtues and charismatic leadership. Electronic Journal of Business Ethics and Organization Studies, 17 (2), 3-14.

Kamtekar, R. (2004). Situationism and virtue ethics on the content of our character. Ethics, 114 (3), 458-491.

Katajajuuri, J.-M., Silvennoinen, K., Hartikainen, H., Heikkilä, L. \& Reinikainen, A. (2014). Food waste in the Finnish food chain. Journal of Cleaner Production, 73, 322-329. 
Ketola, T. (2017). Genuine sustainability as virtuous sustainable development. In A.J.G. Sison, G.R. Beabout, \& I. Ferrero A. (Eds.) Handbook of Virtue Ethics in Business and Management (pp. 1367-1370). Dordrecht: Springer.

Kozinets, R.V. \& Handelman, J.M. (2004). Adversaries of consumption: Consumer movements activism, and ideology. Journal of Consumer Research, 31 (4), 691-704.

MacIntyre, A. 1981. After Virtue: A Study in Moral Theory. London: Duckworth.

Morgan, R.M. \& Hunt, S.H. (1994). The commitment-trust theory of relationship marketing. Journal of Marketing, 58 (July), 20-38.

Murphy, P.E., Laczniak, G.R. \& Harris, F. (2017) Ethics in marketing. International cases and perspectives. New York: Routledge.

Pietilä, S. (1976). Sisällön erittely. Helsinki: Gaudeamus.

Porpino, G. (2016). Household food waste behavior: Avenues for future research. Journal of the Association for Consumer Research, 1(1), 41-51.

Simmel, G. (1957). Fashion. American Journal of Sociology, 62, (6), 541-558.

Solomon, R.C. (2003). Victims of circumstances? A Defense of virtue ethics in business. Business Ethics Quarterly, 13 (1), 43-62.

Solomon, R. (2004). Aristotle ethics and business organizations. Organization Studies, 25, 1021-1043.

Spiggle, S. (1994). Analysis and interpretation of qualitative data in consumer research. Journal of Consumer Research, 21 (3), 491-503.

Takala, T. (1989). Discourse on the social responsibility of the firm in Finland, 1930-1940 and 1972-1982: Theoretical framework and empirical findings. Scandinavian Journal of Management, 5 (1), 5-19.

Takala, T. (2012). Essays on Business and Leadership Ethics. Annales Universitatis Turkuensis, Series B, No. 348. Turku: University of Turku.

Thompson, C.J. \& Coskuner-Balli, G. (2007). Countervailing market responses to corporate co-optation and the ideological recruitment of consumption communities. Journal of Consumer Research, 34, 135-152.

Van Doorn, J. (2016). Commentary: Why do we waste so much food? A research agenda. Journal of the Association for Consumer Research, 1(1), 53-56.

Velasquez, M.G. (1998). Business Ethics: Concepts and Cases. $4^{\text {th }}$ ed. New Jersey: PrenticeHall. 
Welch, D., Swaffield, J. \& Evans, D. (2018, May 17). Whos's responsible for food waste?

Consumers, retailers and the food waste discourse coalition in the United Kingdom. Journal of Consumer Culture. DOI: 10.1177/1469540518773801 
Table 1 Summary of data

\begin{tabular}{|c|c|c|}
\hline $\begin{array}{l}\text { Years of } \\
\text { publication }\end{array}$ & $\begin{array}{l}\text { Number } \\
\text { of articles }\end{array}$ & Examples of magazine/newspaper titles and headlines \\
\hline 1885-1917 & 26 & Various newspapers/magazines \\
\hline \multirow[t]{6}{*}{$1885-1899$} & 1 & $\begin{array}{l}\text { Koitar: Savo-Karelian association's album (Koitar: Savo-karjalaisen } \\
\text { osakunnan albumi) }\end{array}$ \\
\hline & 6 & Finland's health care magazine (Suomen terveydenhoito-lehti) \\
\hline & 2 & $\begin{array}{l}\text { Koitto: Teacher associations' health and temperance publication } \\
\text { (Koitto: Opettajayhdistyksen terveys ja raittius julkaisema) }\end{array}$ \\
\hline & 1 & Home and society (Koti ja yhteiskunta) \\
\hline & 2 & Readings for Finland's soldiers (Lukemisia Suomen sotamiehille) \\
\hline & 1 & Dawn of day (Aamun Koitto) \\
\hline 1900-1906 & 11 & $\begin{array}{l}\text { Field man (Peltomies), Threshold of a new era: Finland's worker album } \\
\text { (Uuden ajan kynnyksellä: Suomen työväen alpumi), Tuulikki, Pellervo, } \\
\text { various other titles }\end{array}$ \\
\hline $1907-1911$ & 2 & $\begin{array}{l}\text { Home and society (Koti ja yhteiskunta), Housewife magazine: The } \\
\text { voice of Martta-association (Emäntälehti: Martta-yhdistyksen } \\
\text { äänenkannattaja) }\end{array}$ \\
\hline $1912-1917$ & 14 & $\begin{array}{l}\text { Finland's woman (Suomen nainen), Hunting and fishing (Metsästys ja } \\
\text { kalastus), Shepherd-messages: An evangelic monthly periodical } \\
\text { (Paimen-sanomia: evankelinen kuukausilehti), various other titles }\end{array}$ \\
\hline 2008-2017 & 199 & Helsingin Sanomat \\
\hline 2008 & 1 & Food purchased by the elderly should be cheaper (12.11.2008) \\
\hline 2010 & 4 & It is imperative to intervene in wasting food (3.11.2010) \\
\hline 2011 & 6 & Attacking hunger with small acts (27.2.2011) \\
\hline 2012 & 14 & This is how you can reduce food waste (20.4.2012) \\
\hline 2013 & 10 & Minimising food waste requires expertise (3.3.2013) \\
\hline 2014 & 25 & Novel package tells you whether the food is spoiled (27.9.2014) \\
\hline 2015 & 37 & $\begin{array}{l}\text { Startup wants to end food waste - restaurant day involved in the } \\
\text { campaign (14.8.2015) }\end{array}$ \\
\hline 2016 & 56 & Food made of leftovers becomes popular at once (3.2.2016) \\
\hline 2017 & 46 & $\begin{array}{l}\text { Overconsumption day and resource shortages remind us that the } \\
\text { ability of nature to renew is being tested (21.4.2017) }\end{array}$ \\
\hline
\end{tabular}


Table 2 Changing themes and virtues of food waste in different times

\begin{tabular}{|c|c|c|}
\hline & Agrarian society & Mature consumer society \\
\hline Local to global & $\begin{array}{l}\text { Leftover food is a matter of coping } \\
\text { with scarcity in households and } \\
\text { individuals } \\
\text { Waste from valuable, but scarce, } \\
\text { resources in consumers' everyday } \\
\text { lives is managed. } \\
\text { Frugality, Simplicity, } \\
\text { Moderation }\end{array}$ & $\begin{array}{l}\text { Food waste is a global issue with } \\
\text { significant economic and ecological } \\
\text { impacts that lead to climate change } \\
\text { and pose a threat to mankind. }\end{array}$ \\
\hline $\begin{array}{l}\text { Nature of food } \\
\text { waste }\end{array}$ & $\begin{array}{l}\text { Leftover food is sometimes } \\
\text { generated in households. } \\
\text { Small amounts of food are stuck } \\
\text { on pans and pots. } \\
\text { Frugality, Moderation } \\
\text { Respect }\end{array}$ & $\begin{array}{l}\text { Food waste is generated at all stages } \\
\text { of the food chain. } \\
\text { Enormous volumes of edible food are } \\
\text { thrown away. } \\
\text { Vices rather than virtues } \\
\text { Standards of excellence lacking }\end{array}$ \\
\hline $\begin{array}{l}\text { Risks of waste - } \\
\text { from contamination } \\
\text { to inequality }\end{array}$ & $\begin{array}{l}\text { Leftover food holds contamination } \\
\text { potential and may cause diseases. } \\
\text { Respect, Benevolence, } \\
\text { Transparency, Care }\end{array}$ & $\begin{array}{l}\text { Donating unsold food to charity } \\
\text { portrays inequalities in society. }\end{array}$ \\
\hline $\begin{array}{l}\text { Benefits from food } \\
\text { waste - from feeding } \\
\text { animals to business } \\
\text { models }\end{array}$ & $\begin{array}{l}\text { Feeding domestic animals and } \\
\text { pets. } \\
\text { Smart reuse of excess food helps } \\
\text { save money. } \\
\text { Frugality, Simplicity, } \\
\text { Moderation, } \\
\text { Benevolence, Care }\end{array}$ & $\begin{array}{l}\text { Ideology and lifestyle in consumer- } \\
\text { identity construction. } \\
\text { Opportunities to create sustainable } \\
\text { business models. } \\
\text { Trust } \\
\text { Potential for defining virtues }\end{array}$ \\
\hline
\end{tabular}

